\title{
SEX EDUCATION - TEACHING FOR RESPECT: The perception of different social actors about different levels of education
}

\author{
Laysa Adrielle Juvêncio Nascimento*1; Janaina Barbosa da Silva²; Andreza Júlia de Lima³; Rayane \\ Victoria Rodrigues Chagas ${ }^{4}$; Lucineide Barbosa Lima ${ }^{5}$
}

1 Professor, Specialist at FAR - Anchieta College of Recife - Pernambuco - Brazil

2 Professor at private school system - Pernambuco - Brazil

3 Pedagogue, specialist in Special Education and Inclusive Practices at FACOL- Pernambuco - Brazil

4 Undergraduate of the Biology Course at University Center of Vitória de Santo Antão - UNIVISA- Pernambuco - Brazil

5 Professor, specialist, high school education school in the state school system of the State of Pernambuco - Brazil

E-mail adresses: proflaysanascimento@gmail.com (Laysa Adrielle Juvêncio Nascimento), prof.janainabarbosa27@gmail.com (Janaina Barbosa da Silva), andrezalima_1@hotmail.com (Andreza Júlia de Lima), rayane.vit.rodrigues@gmail.com (Rayane Victoria Rodrigues Chagas), limalucineide.b@gmail.com (Lucineide Barbosa Lima)

*Corresponding author

\section{To cite this article:}

Nascimento, L.A.J.; Silva, J.B.; Lima, A.J.; Chagas, R.V.R.; Lima, L.B. SEX EDUCATION - TEACHING FOR RESPECT: The perception of different social actors about different levels of education. International Journal of Sciences. Vol. 2, No. 1, 2021, pp. 75-82. ISSN 27635392 .

Received: 06 29, 2021; Accepted: 06 30, 2021; Published: 07 15, 2021

\begin{abstract}
This article arose from concerns coming from observations of the day-to-day of a school of the Private Network of the municipality of Caruaru, in Pernambuco. Concerns related to the sexuality of the students, which is increasingly a surfaced. Therefore, our general objective is: To understand how Sexual Education is approached by different actors, at different levels of Education. For, often, they only deal with this theme with adolescents, forgetting that children also have a sexuality. Thus, we used the ethnographic research, based on Marli André, with bibliographic research, daily observations and interviews with teachers, management team and students. Thus, we have a variety of visions in the face of the same theme, which is still full of taboos and prejudices. However, our children and adolescents need to debate about it and talk about what they feel and what they live, learning respect (to themselves and others).
\end{abstract}

Keywords: Sex Education. Sexuality. Gender. Respect.

\section{Introduction}

The human being is a sexual subject. Parts of the body are eugenic zones and, from the very beginning, sexuality is present in your life. The child shows, early on, curiosity for his body, although differently and at a different level from the adult. However, in adolescence, sexuality smore sharp. Period when many seek their sexual identity (ESTACHESKI, 2016).

In this sense, the school cannot remain inert to this theme, because the school institution is dynamic; it was not made just to teach formal content. It consists of active subjects, full of life, with their problems and concerns: it is a living wheel in which it is necessary, to deal with these issues inherent to being a year, both in Early Childhood Education and in the years following until high school (ANDRIGUETO,
2016).

Thus, Sexual Education is extremely important in all stages of teaching, because with appropriate languages for each age group, the subject needs to be addressed. Issues of sexuality are often only addressed in the 5th year (Elementary School I), in the 8th grade (Elementary School II) and in the 2nd year (High School), because it is mandatory content of the National Common Curriculum Base (BNCC). Moreover, this theme is judged as irrelevant. Not to mention that only subjects related to the physical part of the human are presented in textbooks, leaving aside the social and psychological aspects of the subject. Sexuality, today, is much more than the genitals, the sexual act, prevention of Sexually Transmitted Diseases (STIs), are also issues of gender, homophobia, respect, pedophilia, harassment and many other aspects (BRAZIL, 1997). 
Thus, sexuality is a subject to which the school cannot dodge or transfer responsibility only to parents. The choice of this theme becomes the object of study because it understands the urgency of sexual counseling to be given, in understandable terms and, in due course, to children, adolescents and even adults (school professionals). The approach to the theme is of great relevance to school life, but many teachers still refuse to talk about sexuality, imposing barriers. This is its professional importance, as well as its social relevance through the promotion of actions that can take place within and outside the school environment (ANDRIGUETO,2016).

Thus, this article has as its general objective: To understand how Sexual Education is approached by different actors, at different levels of Teaching. Thus, the specific objectives aim to explain the perspective of each group of subjects under analysis: 1 . To analyze how teachers, from different levels, approach Sexual Education; 2. Reflecting management acts in the face of sexual education issues in daily life; 3 . Identify the way students deal with sexual issues, as well as see Sex Education in their school.

\section{Methodology}

In a "untangle" of observations of the daily life of a private school, in the municipality of Caruaru-PE, added to the current reality, a concern arose: How is Sexual Education approached by different actors, at different levels of Education?, because, as it is more latent in adolescents, they still promote some actions for them, but forget about children, who need information as well.

To develop the research around the problem outlined, we carried out an articulation of techniques adopted by ethnographic research, where what is aimed is the discovery of new concepts, new relationships, new ways of understanding reality." (ANDRÉ, 1995, p. 30). Of these methodologies, we list: a) bibliographic research, to support the interpretation of the data collected in the research field; $b$ ) observation of school daily life, analyzing the constants and variants of the subjects of the school in question; c) interviews with teachers from Early Childhood Education to High School, elementary and high school students, professionals from the management team. The procedures, recorded above, are the central framework of this research, which aims at the systematization of data, based on the ethnographic approach. It is noteworthy that the work relates and emphasizes the intersections of the context, in view of the view of different subjects and the daily school.

In the course of the research, it was noticed how interesting it would be to know the opinion of a School Advisor, in view of the theme, since it has a fundamental role in the formation of the student. However, in the investigated school, the figure of this professional is non-existent. Sharpening our curiosity to understand how much the Advisor could make a difference in this scenario.

However, the school has a fundamental role in this formation, providing a maturation of consciousness and generating an effective and emancipatory constitution of students in relation to sexuality. Those who have the daily task of providing ready-made and finished formulas know that educating is a continuous act of learning that also evolves with a good sexual orientation and with the life experience of professionals.

\section{Results}

\subsection{The different perspectives of the same sexual education}

Savor an ice cream, relax with a massage, enjoy a person's kiss: everything that gives us pleasure, is directly related to sexuality. Therefore, since we are born, we have pleasure and sexual desires: the act of breast-feed is our first contact with pleasure, which depends on survival. However, these questions, for common sense, have no character of sexuality, they think that only the sexual act itself constitutes sexuality.

These days, we cannot deal with sexuality, restricting it to sexual intercourse, as this is just the tip of a huge iceberg submerged in the ocean of a subject's sexuality. In this hidden part, we find the issues of gender, harassment, homophobia, rape, abortion, among many others in which they seem forbidden subject. Of course, the sexual act is still taboo, imagine all these other dependents. That is, if sex is still seen as something mysterious, vulgar, sinful, excluding from this the essence of which is an indisputably vital physiological function to the human being, let the more all the social burden that comes along with it.

In this way, it is noticeable how our children are increasingly sensual, our teenagers increasingly malicious and our young people increasingly massified by a retrograde culture... With this in mind, the school plays a key role in this training process. Discussing the physical, biological and social issues of sex, from an early age, is ideal for the construction of "healthy" subjects, conscious in the face of a range of factors, needing to be understood without embarrassment, with something intrinsic and extrinsic to the human being. In the present and that projects the future, seeking to unlink the sexuality of taboos and prejudices, and, concatenates them to pleasure and life. "Therefore, teaching, debating and knowing gender relations and sexual diversity in the classroom is to allow the student to recognize and validate this difference, as a valid knowledge and advisor of their practical-political actions" (CREMA, in: BUENO, ESTACHESCKI, CREMA, 2016, p. 59)

When a school treats these matters in the classroom, it demystifies all the taboo that involves sex. As we said earlier, they understand their own sexuality, respecting and respecting the other. As this happens, the individual will not be homophobic, does not rape, does not besedia, because there is RESPECT, before anything.

In 1997, the Ministry of Education and Culture (MEC) launched the National Curriculum Parameters (PCN's) which constitute as references for quality education. For a better understanding, they were divided on the Areas of Knowledge (Portuguese Language, Mathematics, Natural Sciences, History, Geography, Art and Physical Education) and 
transversal themes (Ethics, Cultural Plurality and Sexual Orientation, and Environment and Health). Thus, we have a document that asks that sexual orientation be worked in the classroom, it is not necessary a specific class, because it is not in the Common National Curriculum Base, but that is worked transversally in the formal disciplines.

'When it comes to sexual orientation, we seek to consider sexuality as something inherent to life and health, which is expressed in the human being, from birth to death. It relates to the right to pleasure and the exercise of sexuality with responsibility. It encompasses gender relations, respect for oneself and the other and the diversity of beliefs, cultural values existing in a democratic and pluralistic society. It includes the importance of preventing sexually transmitted diseases/AIDS and unwanted pregnancy in adolescence, among other controversial issues. It intends to contribute to the overcoming of taboos and prejudices still rooted in the Brazilian sociocultural context. (BRAZIL, 1997, p. 267)".

However, even with this pattern being followed, this is not what we see in many schools in our country. The PCN's are for the grades of elementary school, so the Sexual Orientation was to be worked in a transversal way, however, when it comes to are only in science classes, in the series in which the National Curriculum Matrix addresses the subject of the Reproductive System and Human Reproduction, excluding this, rare are the discussions on the subject. In Early Childhood Education, the subject is almost non-existent, because it is thought that children are asexual and, in high school, the approach occurs in the same way as, in elementary school, only in specific classes. We did a research in a private school in the city of Caruaru-PE, in which we interviewed teachers, management staff and students, as well as daily observations so that we can analyze how Sexual Education is approached at the different levels of teaching of this school, in the view of these actors.

\subsection{Sexual Education: the teaching perspective}

The teachers interviewed were four: P1, teacher of Early Childhood Education, of students aged 5 years; P2, teacher of the 2nd year and 5th grade, elementary school I; P3, Science Teacher, Elementary School II; and, P4, biology teacher, high school. We asked six questions related to the textbook, the classes taught, the reaction of the students, the sources of information of the students, the efficiency of the methods used in the school and, how the management acts in the face of sexual education issues.

When dealing with the textbook, all subjects agreed that it addresses the theme in a clear way, according to the appropriate age group, with the exception of $\mathrm{P} 4$, which stated that the book is not comprehensive, as it does not bring issues related to social issues of sex. The book is a support for the teacher, but who plans the class and the minister are the teachers themselves, so one has to be prepared for the insurgent questions.

Thus, the following question relates to the way teachers explain the theme of sexuality in their classroom. The P1 says that only answers what is asked and, as it teaches in Early Childhood Education, informs that the frequency of questions is very sporadic. P2 explores spontaneously, since, directly, it is the first contact that students have with the subject in the classroom, but some already have some knowledge about it. P3 and P4 have a very similar way of working, with debates and conversations.

However, P4 names its pedagogical action "put on the wheel". Here is his explanation of the practice: "We make a circle and whoever takes the paper has to represent, in the middle of the circle, hence the name. Thus, they represent, in some roles have social situations that involve more than the sexual acts themselves. E.g.: If you were a father, how would you cope if your son was gay? Because in my classes are addressed three points of sexuality: 1 . The physical, which is the common; 2. The psychological, which are gender identities, these things; and, 3. The social environment. Because, nowadays, sexuality goes far beyond STD".

This speech of P4 not only translates its dynamics, in the classroom, but reveals its vision of Sexual Education in the face of reality. By discussing these social issues, students build their ideologies according to the opinion of the other, learning to listen to others.

"The debate about gender may break with the established
idea that the guilt for the rape suffered is the victim and
not the aggressor, that the fault for violent death is the
transvestite who did not fit the imposed rule, and with the
idea that it is because they do not fit that homosexuals
should hide and not be entitled to study, life, dignity, so
as not to scandalize people who cannot see humanity in
other people. (ESTACHESKI, in: BUENO,
ESTACHESCKI, CREMA, 2016, p. 68)".

Any subject worked in the classroom requires a reaction from the students, since the teacher is there speaking to them. Even if, with apathy, every student outlines a negative or positive reaction. And when we talked about the students' reaction, the teachers' responses were the most varied, demonstrating the disparity between the levels of education. The students of P1 show no interest in the theme, he believes, that because of age. Thus, it is notorious that old idea that sexuality is only the sexual act itself. In the P2 room, students act in two ways: with shyness and/or astonishment and with delivers. These students already have an age group between 10 and 11 years, are entering puberty and, some already have some knowledge about the subject. The students of P3, students of Elementary School II, the relaxed is the one that is in one, because many are in a phase of games, in which they "take wave" of everything and everyone. For P4, as he teaches in high school, students are curious, ask questions and comment on their longings, demonstrating certain maturity, in which they begin to reflect on who they are as social subjects. 
Wanting to see and touch the genitals (Early Childhood Education) and speak profanity (nomenclature not suitable for the genitals, in Elementary and High School) are actions that happen constantly in the classrooms and often in front of teachers. Many ignore these behaviors and, this, causes the search for information with colleagues, who think they know something. Nowadays, the champion in taking questions is the Internet, but we have to be careful that these students are accessing, because on the Web not everything is true. These sources of information were those mentioned by the teachers analyzed, reverberating the concern with these accesses. The P4 also cited that, a very small portion, takes questions with parents, but that is rare. At this moment, we need to reflect on family action as well, as the theme is delicate and there are still taboos to overcome, a partnership with parents is essential. For the child/adolescent to live healthily with these sex-related issues, both parents and teachers must help them understand what goes on at every moment of their life. Therefore, since Early Childhood Education, it is necessary to treat these issues naturally, without judging according to an adult, because being frightened by situations can cause them to feel ashamed of their own sexuality.

Thus, are the pedagogical actions carried out at school sufficient and effective for a real Sexual Education? At this point, the answers were the most diverse: "It is enough for the beginning." (P1); "It's efficient, but it should have more resources." (P2); "I don't think it's enough; it takes better guidance from parents and interdisciplinary work throughout the year." (P3); "It's efficient to some extent or I can say that it's efficient as much as it should be after all even knowing all the methods and issues, they won't become aware in a semester or a class." (P4). In these discourses, we noticed that teachers need greater training to deal more closely with these themes. Organizing sporadic lectures has no effect. What really works is to work the subjects without fear or prejudice, after all, some of the issues need to be taken up, with different degrees of deepening as doubts and the level of understanding of students change. Therefore, it should be a constant work, but for this, all teachers of the school must have continuous training, because the subjects do not arise only in science classes.

"It is necessary to think of a training that can clarify doubts about gender and sexual diversity. And when I say training, I believe in the responsibility of teacher training courses teaching and undergraduate courses in undergraduate and continuing teacher training. In the undergraduate courses, the theme is only discussed if in the collegiate course there are teachers who study the subject and offer elective subjects, hardly the theme makes up the disciplinary matrix. In continuing education there is a diversity of courses being offered, unfortunately these courses reach only those interested in the theme and not the whole school and it is necessary to think about strategies that exceed the lack of understanding of the theme. (ESTACHESKI, in: BUENO, ESTACHESCKI, CREMA, 2016, p. 72)".
Thus, when it comes to continuing education, we touch on the core of school management, which should provide opportunities not only for teachers, but to treat daily manifestations of students' sexuality, in a respectful and appropriate way for each age and not masking the problems that arise.

When we ask how the Management of this school acts in the face of some "problems" that appear, the contradiction between the levels of education is noticeable. P2 says that management is retrograde, while P3 and P4 say they have management support and that it has a considerate look. Thus, we realized that the management team has a greater focus for adolescents, forgetting that if we work on these issues from an early age, we will avoid further problems.

Therefore, according to the data collected, we realize that it is increasingly urgent to train teachers, because treating Sexual Education should not be in charge only of the teacher of a given discipline or series. From very young, children have sexual demonstration either by imitation of their parents or inherent in themselves, so the attention of teachers should also turn to Early Childhood Education. It is better to start working the subject in an informative and oriented way, because when they reach adolescence, these students will be well informed, knowing how to respect themselves and others. The challenge for the teacher is enormous: while preserving the intimacy of children/adolescents and not blaming them for manifestations of sexuality, he is responsible for an educational process that addresses individual and group differences, customs and belief values. And, this is essential in both Early Childhood Education and High School.

\subsection{Sexual Education: the perspective of Management}

In this second part of the research, we interviewed two people from the management team: pedagogical coordinator and supervisor. We wanted at least one manager, but we couldn't get in touch with any of them. Therefore, our subjects are: G1, pedagogical supervisor and G2, pedagogical coordinator. The questions were very similar to those we asked teachers: how Sex Education is worked; how management deals with day-to-day situations related to the theme; students' reaction; the source of information for students; and, if the work done is efficient.

The school has the role of making the understanding, clarifying the issues inherent to the human being and the world, because it must train citizens, so students must be aware of all scientific and social knowledge so that they can enjoy, without danger, freedom. In this sense, school management is also fundamental in terms of Sexual Education.

Thus, in the school studied, Sexual Education is worked, according to G1, in science classes and lectures. G2, on the other hand, makes a difference regarding Early Childhood Education, "which is only a theme when a question arises". This singularity is important because it is, in Early Childhood Education, that children begin to wonder about the birth of babies, for example. That way, they're in the question phase, so they're going to ask the first person who shows up. At this 
time, the important thing is to remove the doubt of what the child actually asked, without anticipating other doubts and thus ensuring access to information as they make sense to them. Thus, when an episode arises that refers to sexuality and worries management, it calls the parties involved to talk. Sometimes, with severe punishments to be applied (e.g., when a student, from Elementary School II, was excited in the classroom and was suspended from classes) and others with affectionate conversations (e.g., when a high school student was in doubt about his sexuality). When these manifestations emerge, management seeks, as a matter of urgency, to promote lectures and debates. However, we see that these actions are aimed at adolescents, leaving children out of this training process, in which they could make debates focused on their field of knowledge and appropriate to the age group. Then, it comes to mind what Foucault called "Pedagogization of the child's sex", in which people must educate children, who are sexual beings by nature.

"[...] double statement that almost all children dedicate themselves or are likely to engage in sexual activity; and that such sexual activity, being undue, at the same time, "natural" and "against nature", it brings physical and moral, collective and individual dangers; children are defined as "injunctions" sexual beings, at the same time below and already in sex, on a dangerous demarcation line; parents, families, educators, doctors and, later, psychologists, everyone must continually take care of this precious and risky sexual germ, dangerous and danger. (FOUCAULT, 1988, p. 115)".

As for the students' reaction, G1 brings an interesting question: "That when they feel safe in relation to some teachers, the procure to answer their doubts". This speech is of a preciousness without size, because security is the basis of any relationship and, if the student trusts a teacher, he will take away all the questions and with people indicated to answer. In this item, we realize that being a teacher/educator goes far beyond transferring mere scientific knowledge, being a teacher is dealing and training people in the most human sense of the word.

Having this security in the teacher, the student does not need to seek information from unreliable sources, such as erroneous websites and/or friends who think they are experts. It is perceived in the statements of G1 and G2, the minimum presence of a few students who talk to their parents. Unfortunately, the family leaves much to be desired, when it comes to any subject related to sex, leading, mainly, adolescents to learn or satisfy their curiosities with wrong information. The family and the school are the elements most appropriate to the guidance of children and young people.

In this sense, the actors agree that the actions carried out by the school are not sufficient for a quality Sex Education and that it is necessary a constant work of orientation, focused not only on physical and health issues, but also sociocultural, because the school that should embrace differences, can be the most oppressive environment that exists. We have to be careful with bullying and promote respect for women, homosexuals, because when you know something, you fight prejudice.

\begin{abstract}
"Actions are necessary for gender education work, combating violence against women and homophobia in schools, arises from the objective need in project content, the joint treatment of gender, diversity and combating inequalities and violence should consider gender references and the search for equality. Thus, we seek help through scientific knowledge and not through values and beliefs, personal common sense, educators through the development of social awareness formation and production of didactic-pedagogical support materials. (ANDRIGUETO, in: BUENO, ESTACHESCKI, CREMA, 2016, p. 80)".
\end{abstract}

Therefore, we note that management needs to be more active in the daily life of students, in the face of sexual issues, not to act only when some "problem" arises, which makes it contradictory in many times. Making "dirty", the physical issues of sexuality and zealously addressing psychological issues, where both situations deserve the same attention and care. A well-conducted Sex Education reconciles the biological, physical, psychological, social realities that are innate to its human. This will undoubtedly be a powerful contribution to the effective construction of real citizens.

\subsubsection{Sexual Education: the non-existent perspective of the School Advisor}

Much is said about School Management and Pedagogical Coordination, however, sometimes the School Orientation is cornered, devalued and, in some schools, non-existent (as is the case of the School Institution studied). This is because this position is not given due importance, knowing that it has a unique role in the integral formation of the subject.

"School Orientation (OE) is an organized and permanent process that exists in the school. It seeks the integral formation of students (this process is appreciated in all its aspects, considered capable of improvement and realization), through scientific knowledge and technical methods. The Educational Orientation is a system in which it takes place through the relationship of help between Advisor, student and other segments of the school, the result of a relationship between people, carried out in an organized way that ends up awakening in the student opportunities to mature, make choices selfknowing and taking responsibility. (MARTINS, 1984, p.87)".

Thus, a professional of this importance could not fail to be present in a school, since it is the same one who is in direct contact with the student, in order to guide him on the path he will follow (which is why the name of the function lives up to its main attribution). Thus, with regard to Sexual Education, the School Advisor would have a fundamental role in any and 
all school areas, due to the fact that his work is concatenated to the daily life of the school, with the daily life of the subject in formation (and everything that goes on within it, which helps in its growth as a person).

Therefore, we realized that a school that does not have this professional ends up overloading its Pedagogical Coordinator, who previously would have the function of acting in front of teachers. However, without the figure of the School Advisor, the Coordinator takes for himself, assignments aimed at the students.

"It is worth mentioning that pedagogical coordination, whose role is guided by the systematic monitoring of teachers' pedagogical practice, has a series of attributions, usually described in the rules of schools, including: responsible for the pedagogical activities of the school; monitor the teacher's activity in the classroom; supervise the development of projects; discuss the politicalpedagogical project; provide assistance to the teacher; coordinate pedagogical meetings; organize student classes and monitor assessment processes; organization and evaluation of the school; take care of the evaluation of the teaching staff and the pedagogical plan; attend to parents and students in their difficulties; and propose to coordinate continuing training actions of the teacher. (DOMINGUES, 2014, p. 15 - our griffin)".

Thus, it is notorious that the Coordinator encompasses many functions, causing the non-fulfillment of many of them. Leaving a huge gap in this evolutionary process of the student. And, as for Sex Education, the student is left without a very important support, which the Coordinator often cannot offer, not because he does not want to, but because his time does not allow.

Therefore, the School Advisor makes a huge lack in our institutions, where they could help in the construction of the idea of Sexuality / Gender of students, contributing to a healthy vision and consistent with the principles of them. Thus, students would not need to seek erroneous information in disbelieving places, but would have confidence in the character who would be there to support them in building their ideas.

\subsection{Sex Education: the student optics}

We saw the opinions of the teachers, the management team and, nothing fairer than listening to our main target: the students. Every pedagogical action is aimed at the student himself, so it is necessary to understand what they think about these issues. Thus, our subjects were surveyed were three: A1, elementary school student I (5th grade); A2, elementary school student II (8th grade); and, A3, high school student (2nd year). We can't interview early childhood education students. With the students the answers were more succinct, for this is still a subject with a huge load of taboos, prejudices, sins. The questions followed the same line of reasoning as with the other previous actors: about the textbook; treatment of the theme in the classroom; reaction of him and colleagues; source of information; effectiveness of the actions carried out; and how management acts in the face of Sexual Education.

Referring to the textbook, the answers were very generic: "yes, normal". However, A1 (the youngest) shoots us with: "I think so, because if you wouldn't learn from other people's mouths, in the wrong way". It shows that you don't have to seek information from anyone. However, the same contradicts itself when asked about where it seeks information related to the subject and reveals to be friends. The other subjects give different answers: teachers and parents (A2) and only in the classroom (A3). This makes us curious, because the other actors, the adults (subjects previously treated), thought that the students sought information on the Internet and none of the students quoted it. And, it makes us a warning when mentioning only friends and, in the classroom, because this last term is very broad: it can be in classes with teachers or with colleagues in the classroom, and this term is part of a high school student, who already has an active sexual life. Therefore, it assumes that it needs more care and information. In the meantime, $\mathrm{A} 2$ draws attention, as he reports that he talks with parents and teachers, revealing a relationship of trust. When students learn from peers, they usually do so through words loaded with malice, so it is important the role of parents and teachers in training these children/adolescents in the face of sex.

When you don't have this dialogue with parents and/or teachers or out of shame, many students act with mockery when it comes to the subject. It is normal, the usual relaxed of adolescents and the shame of children, with shy laughter.

Other larger ones seek to ask questions in the face of situations experienced. Unfortunately, these doubts are only taken, in science classes, "the other teacher's kind of avoid talking" (A2) and A3 complete "with an emphasis on STD's and prevention." But is that all our students need? Adolescents have hormones on their skin, they need to take care of themselves, but many are at an exorbitant psychological load without knowing if they like boys and/or girls; if that touch of the stepfather was affection or malice ... Among so many other examples we could mention. Therefore, the educator of any discipline has to be prepared to help his student and not pretend that it is not his function. Every teacher has a social function in front of our student and society, but we cannot let it go unnoticed. "The teacher must be prepared to understand this reality and contribute to effective changes in social enlightenment and improvement using the school as instrumentalization of transformations." (ANDRIGUETO, in: BUENO, ESTACHESCKI, CREMA, 2016, p. 83)

In this sense, not only the teacher should be prepared for the surprises of the day to day, but also the management as a whole. In the students' view, they do not know how the management team acts in the face of issues related to sexuality and, in a unanimous speech, mention the need for more campaigns, projects, debates. Exemplifying with A3's speech: "It is a very relevant subject to be only in the classroom. We have many taboos when it comes to sexuality, because they see the choices and choices and, with the living in a secular 
country, but with a religious culture still very strong, becomes a subject less debated, exposed. This line of this student reveals the urgency of more educational actions in this field of knowledge, the students increasingly have greater access to information, but do not have a discernment to know the real origin of them. In this scenario, there is the fundamental importance of teachers/managers in discussing and helping to train critical and healthy citizens (not only biologically), far from a religiosity cover.

"Humanity in us is conditioned on our ability to look at and value the other person in their humanity. What "human being" would we be destroying when debating gender? What idea of humanity is this that excludes the diversity and humanity of the other person and considers family only one that follows its pattern and understands as valid only faith that refers to its spiritual understanding? (ESTACHESKI, in: BUENO, ESTACHESCKI, CREMA, 2016, p. 67)".

Given what we have seen with the students, we realize that teachers and management are far below our students, those who often do not know how to act in certain situations and only address the subject sporadically. Children and adolescents are full of longings and questions, debates that have to be called into question for their own construction. However, adults are full of a load of religiosity, where dealing with these issues is a sin. However, sin is not to enlighten our students in the face of topics relevant to the current and peopletrainers. It sins in hiding the truth from students, which can lead them to a true sin.

\section{Conclusions}

One school, several educators (management and teachers), hundreds of students... a perfect field for any search. There, millions of social, cultural, biological, pedagogical issues are boiling. However, our gaze turned to Sex Education, which is necessary in all school age groups. Students also need to learn about sex (biologically defined), sexuality (relation to people by whom we feel attraction) and gender (characteristics socially attributed to each sex). These issues are increasingly latent in our reality and the school cannot "turn a blind eye" to such. Students need to understand each other biologically, physically and also socially, psychologically. Thus, he learns to see the different with other eyes, which is different, but not as a threat to his sexuality.

So, what would be the main purposes of a Sex Education? First, to remove from the problem "sex" the aspect of mystery and sin, to make it clear, that it is a natural function goal of our life, which must be accepted and understood without constraints. Secondly, to enlighten our students about sexuality, about gender, giving them correct and real knowledge about these aspects of the human individual. And, thirdly, to alert students of both sexes to the conduct to be followed in the face of the inevitable and imperative requests of libido (sexual appetite), of the dangers and frustrations to avoid.

Thus, our problem comes back to the fore: How is Sexual
Education approached by different actors at different levels of Education? and we noticed that, in this school, much still needs to be done. We noticed a difference in discourses in teachers at the levels of education, contributing to the idea that sexual education is not worked, in the series for young children. It was made clear that management is somewhat contradictory, sometimes too severe, sometimes too kind and, that, it is not present constantly, because the students do not know how it acts in the face of sexual issues. The absence of a School Advisor hinders the student's evolution process.

Therefore, we can affirm that teachers need to go through continuous training to know how to deal with these themes, no educator is free to, in front of them, a student to inform that he is homosexual; a student to say he was abused; a student say he did the sex act without a condom... And how will the teachers act? The school needs to prepare its employees for these surprises.

In the discourses of the students, teachers and a portion of the management team, the need for more actions in favor of Sexual Education was categorical. Something that can also be solved with the continuing education of teachers, once they are prepared to act on these surprises, they will be prepared to work interdisciplinary. Every teacher cannot and should not work his specific and compartmentalized discipline. We have so many aspects to explore and broaden the worldview of our learners.

"I consider another form of gender violence not to address such issues in early and continuing teacher education, just as it is violence not to address the issue at school, because silence is a way of collaborating to maintain the status quo. Depriving knowledge is violence because it allows the maintenance of stereotypes and prejudices that generate discrimination. We are responsible for showing possible paths to change. The school needs to educate for nonviolence, for human dignity, so that our students do not become aggressors and our students do not become victims, so that diversity is not treated as a problem. This education for nonviolence is the role of the whole society and the school cannot exempt itself from doing its part, starting with our own learning and our own attitude to verbal, moral, physical, sexual nonviolence. (ESTACHESCKI, in: BUENO, ESTACHESCKI, CREMA, 2016, pp.7778)".

Therefore, we have seen that it is necessary a structured Sexual Education, in this school, but we also cannot forget the adults elucidating to them that the students cry out for a clarification about something so new in their lives through the awareness of sexuality, thus optimizing a critical training to deal with the concerns that are peculiar to them, because any doubt, however simple it may seem, is relevant and pertinent. Our educational actors ask for educational actions. It is clear that our adolescents and adults were not worked consistently in childhood and, it is the role of the school, demystify the idea of sex as something banal, sinful, illicit. We live in a Secular state, but still dressed on a cloak of religiosity, loaded with "no's" who often harvest the roots of children and adolescents who had everything to grow strong and healthy. We are educators not to cut wings, but to teach to fly, respecting 
yourself and others.

\section{References}

[1] ANDRÉ, Marli. Etnografia da prática escolar. Campinas, SP: Papirus, 1995.

[2] ANDRIGUETO, Sergio Antonio. Gênero e Diversidade Sexual, violência contra as mulheres e homofobia na educação escolar, in: Gênero, educação e sexualidades: reconhecendo diferenças para superar [pré]conceitos / Organização: André da Silva Bueno, Dulceli Tonet Estacheski, Everton Carlos Crema Uberlândia: Ed. dos Autores, 2016.

[3] BRASIL, Secretaria de Educação Fundamental. Parâmetros Curriculares Nacionais: temas transversais. Brasília: MEC/SEF, 1997

[4] CREMA, Everton Carlos. Russen e o "novo humanismo" reflexões para a educação e a diferença. in: Gênero, educação e sexualidades: reconhecendo diferenças para superar [pré]conceitos / Organização: André da Silva Bueno, Dulceli Tonet Estacheski, Everton Carlos Crema - Uberlândia: Ed. dos Autores, 2016.

[5] DOMINGUES, Isaneide. O Coordenador Pedagógico e a formação contínua do docente na escola. 1 ed. São Paulo: Cortez, 2014.

[6] ESTACHESKI, Dulceli de Lourdes Tonet. Gênero na escola sim, mas como fazer? in: Gênero, educação e sexualidades: reconhecendo diferenças para superar [pré]conceitos / Organização: André da Silva Bueno, Dulceli Tonet Estacheski, Everton Carlos Crema - Uberlândia: Ed. dos Autores, 2016.

[7] FOUCAULT, Michel. História da sexualidade. Tradução de Maria Thereza da Costa e J. A. Guilhon Albuquerque. Rio de Janeiro, Edições Graal, 1988.

[8] MARTINS, José do Prado. Princípios e métodos da orientação educacional. 2 ed. São Paulo; Atlas, 1984. 